\title{
Perbedaan Komunikasi Terapeutik Perawat Di Ruang Rawat Inap RS Pemerintah Dan RS Swasta
}

\author{
Nova Fitria *), Zahroh Shaluhiyah **) \\ *) RSUD Cut Meutia Lhokseumawe \\ Korespondensi : putri.novit@gmail.com \\ **) Magister Promosi Kesehatan Universitas Diponegoro Semarang
}

\begin{abstract}
ABSTRAK
Dengan adanya kesetaraan peran rumah sakit pemerintah dan rumah sakit swasta dalam meningkatkan kualitas layanan kesehatan di Indonesia, maka setiap rumah sakit harus memberikan pelayanan yang baik dan berkualitas. Perawat merupakan bagian dari SDM Rumah Sakit yang memberikan pengaruh cukup besar terhadap kualitas pelayanan. Pelaksanaan asuhan keperawatan yang baik tidak dapat dipisahkan dari peran komunikasi terapeutik yang dilakukan oleh perawat yang juga merupakan salah satu upaya peningkatan pelayanan kepada pasien. Jenis penelitian ini adalah penelitian kuantitatif dengan desain penelitian menggunakan cross-sectional.

Hasil penelitian menunjukkan ada perbedaan yang signifikan pada pelaksanaan komunikasi terapeutik perawat di RS Pemerintah dan di RS Swasta, dimana pelaksanaan komunikasi terapeutik perawat di RS swasta lebih baik. Faktor-faktor yang berhubungan secara signifikan dengan pelaksanaan komunikasi terapeutik perawat di RS Pemerintah dan di RS Swasta adalah sama, yaitu variabel kepuasan kerja, motivasi kerja, iklim kerja, dukungan teman kerja dan dukungan kepala ruang. Faktor yang paling dominan berpengaruh terhadap kepatuhan perawat di RS Pemerintah dalam melaksanakan komunikasi terapeutik adalah motivasi kerja (OR 36,866); sedangkan di RS Swasta adalah dukungan kepala ruang (OR 28,598). Perbedaan yang bermakna antara RS Pemerintah dengan RS Swasta nampak pada variabel: umur, masa kerja, sikap, kepuasan kerja, motivasi kerja, iklim kerja, dukungan teman kerja, dukungan kepala ruang, dan pelaksanaan komunikasi terapeutik itu sendiri.
\end{abstract}

Kata Kunci: Pelaksanaan, Komunikasi Terapeutik, RS Pemerintah-RS Swasta

\begin{abstract}
Differences Therapeutic Communication Nurse In Inpatient Room Government Hospital And Private Hospital;quality role of government hospitals and private hospitals in improving the quality of health services in Indonesia, causing every hospital should provide a good service and quality. Nurses are part of hospital human resource that considerable influence on the quality of service, and the implementation of good nursing care can not be separated from therapeutic communication. the optimal implementation of therapeutic communication by nurse is one of the efforts to improve services to the patients. The type of this research was quantitative with cross-sectional study.

The results showed a significant differences in the implementation of nurses therapeutic communication between public hospitals and private hospitals, where the implementation of nurses therapeutic communication in private hospital are better. Associated factors significantly with the implementation of nurses therapeutic communication in public hospitals and in private hospitals are the same, the variables are job satisfaction, work motivation, work climate, coworkers support and head of ward support. The most dominant factor that affects the compliance of nurses in government hospitals in implementing therapeutic communication is work motivation (OR 36.866), while in private hospitals is head of ward support (OR 28.598). Significant differences between the government hospitals and private hospitals appears on variables: age, period of work,
\end{abstract}


attitude, job satisfaction, work motivation, work climate, coworker support, head of ward support, and the implementation of therapeutic communication itself.

Keywords: Implementation, Therapeutic Communication, Government-Private Hospital

\section{PENDAHULUAN}

Pelayanan kesehatan merupakan hak setiap orang yang dijamin dalam UndangUndang Dasar Negara Republik Indonesia tahun 1945 yang harus diwujudkan dengan upaya peningkatan derajat kesehatan masyarakat yang setinggi-tingginya.

Dimana Rumah Sakit adalah institusi pelayanan kesehatan bagi masyarakat (UU RI No.36 Th. 2009, 2011). Luasnya wilayah Indonesia dan dengan keterbatasan pemerintah, maka pemberian pelayanan kesehatan kepada masyarakat tidak dapat dilakukan oleh pemerintah saja, tetapi harus mendapat dukungan pihak swasta. Begitu juga dalam SKN, disebutkan bahwa pembangunan kesehatan harus diselenggarakan dengan menggalang kemitraan yang dinamis dan harmonis antara pemerintah dan masyarakat, termasuk swasta dengan mendayagunakan potensi yang dimiliki masing-masing. Oleh karena itu, upaya perbaikan dan peningkatan pelayanan kesehatan (rumah sakit) pemerintah maupun swasta, menjadi perhatian Sistem Kesehatan Nasional (DepKes RI, 2007).

Rumah sakit dinyatakan berhasil, tidak hanya pada kelengkapan fasilitas yang diunggulkan, melainkan juga sikap dan layanan sumber daya manusia merupakan elemen yang berpengaruh signifikan terhadap pelayanan yang dihasilkan dan dipersepsikan pasien. Bila elemen tersebut diabaikan maka dalam waktu yang tidak lama, Rumah Sakit akan kehilangan banyak pasien dan dijauhi oleh calon pasien. Pasien akan beralih ke Rumah Sakit lainnya yang memenuhi harapan pasien (Azwar, 1994). Di Rumah Sakit, sumber daya yang paling banyak menyumbang sebagai pendukung kepuasan kepada pasien, salah satunya adalah perawat. Perawat memberikan pengaruh besar untuk menentukan kualitas pelayanan. Perawat sebagai ujung tombak pelayanan terhadap pasien dan keluarganya di Rumah Sakit, karena frekuensi pertemuannya dengan pasien yang paling sering. Oleh karena itu, mutu pelayanan keperawatan sangat mempengaruhi kualitas pelayanan kesehatan, bahkan menjadi salah satu faktor penentu citra institusi pelayanan kesehatan di mata masyarakat (Aditama, 2004).

Sementara itu hasil penelitian Firdaus tahun 2003 menemukan bahwa kinerja perawat dengan kategori baik hanya sebesar $56,9 \%$ untuk RS. Swasta dan $44,8 \%$ untuk RS. Pemerintah (Royani, 2010). Selanjutnya hasil penelitian Rosenstein 
tahun 2002, Rosenstein dan O’Daniel tahun 2005, menemukan bahwa terjadi persepsi negatif terhadap ketidak puasan dari hasil perawatan disebabkan oleh komunikasi yang tidak baik yang dilakukan oleh para dokter dan perawat kesehatan serta staf divisi penunjang (Abraham \& Shanley, 1997).

Untuk mengurangi ketidakpuasan pasien akan hasil perawatan dari Rumah Sakit, maka pelaksanaan asuhan keperawatan tidak dapat dipisahkan dari peran komunikasi. Seorang perawat tidak dapat melaksanakan tahapan-tahapan dalam proses keperawatan dengan baik tanpa kemampuan berkomunikasi yang baik dengan klien/pasien, teman sejawat, atasan dan pihak-pihak lain (Machfoedz, 2009). Hasil penelitian juga menunjukkan bahwa semakin baik komunikasi terapeutik yang dilaksanakan oleh perawat maka pasien akan semakin merasa puas (Haryanto \& Septyani, 2009).

Tidak dapat dipungkiri, bahwa kepuasan pasien tergantung pada kualitas pelayanan, maka pelaksanaan komunikasi terapeutik oleh perawat merupakan salah satu indikasi untuk meningkatkan kualitas pelayanan yang dirasakan oleh pasien dan keluarganya. Pelaksanaan komunikasi terapeutik yang lebih baik di suatu Rumah Sakit, akan menyebabkan pasien dan keluarganya merasa lebih puas, kembali memilih Rumah Sakit tersebut bila memerlukan

dan menceritakan kepuasannya kepada orang lain. Dimana efek menceritakan kepuasan atau ketidakpuasan suatu produk atau pelayanan jasa dapat mempengaruhi pemilihan produk jasa dari orang lain yang mendengar. Hal ini juga didasari oleh pentingnya informasi dari mulut ke mulut (word of mouth) dalam bauran promosi industri jasa rumah sakit (Lupiyoadi \& Hamdani, 2009).

\section{METODE}

Jenis peneliitian ini adalah kuantitatif analitik, dengan desain penelitian menggunakan cross-sectional. Teknik pengambilan data dengan wawancara menggunakan kuesioner yang telah di siapkan. Tempat penelitian adalah di RS Pemerintah dan RS Swasta. Variabel dependent dalam penelitian ini adalah pelaksanaan komunikasi terapeutik perawat, sedangkan variabel independent adalah karakteristik perawat (umur, jenis kelamin, tingkat pendidikan, masa kerja), pengetahuan, sikap, kepuasan kerja, motivasi kerja, iklim kerja, dukungan teman kerja, dan dukungan kepala ruang.

Populasi target penelitian ini adalah seluruh perawat yang bertugas di ruang rawat inap (selain rawat inap kebidanan, bayi dan anak), baik di rumah sakit pemerintah maupun di rumah sakit swasta, jumlah seluruh populasi adalah 128 orang. Sistem pengambilan sampel dalam 
penelitian ini menggunakan Quota dimana Ellis, Gates, dan Kenworthy tahun Sampling. Penggunaan Quota Sampling 2000 menyatakan bahwa kecemasan yang didasarkan pada jumlah populasi yang lebih dialami seseorang dapat sangat kecil, yaitu 36 orang perawat di RS Swasta. mempengaruhi interaksinya dengan orang Selanjutnya untuk sampel di RS Pemerintah lain, dan Brammer tahun 1993 juga mengikuti jumlah sampel di RS Swasta, menyatakan bahwa pada saat perawat yaitu 36 orang. Maka total sampel dalam merasa cemas, dia tidak akan mampu penelitian ini adalah 72 orang.

\section{HASIL DAN PEMBAHASAN}

Berdasarkan hasil penelitian, mendengarkan apa yang dikatakan pasien dengan baik, sehingga akan sulit untuk menerapkan active listening (Suryani, didapatkan gambaran bahwa 77,8\% responden RS Pemerintah patuh dalam pelaksanaan komunikasi terapeutik, dan $80,6 \%$ responden RS Swasta patuh dalam pelaksanaan komunikasi terapeutik. Beberapa hal yang masih kurang dan perlu mendapat perhatian dalam penerapan komunikasi terapeutik adalah hanya $41,7 \%$ responden di RS Pemerintah yang mencari literature atau bahan panduan lain yang berkaitan dengan penyakit/masalah yang dialami pasien, dan hanya 55,6\% responden yang menenangkan diri sendiri terlebih dahulu sebelum berhadapan dengan pasien. Padahal langkah-langkah dalam tahap persiapan atau pra interaksi sangat penting dilakukan sebelum berinteraksi dengan klien. Karena perawat yang tidak membekali diri dengan ilmu yang berkaitan dengan penyakit/masalah yang dialami pasien dan tidak menenangkan diri sendiri sebelum berhadapan dengan pasien, akan lebih mungkin mengalami kecemasan, 2006). Selanjutnya pada fase pra interaksi ini juga, ada $58,3 \%$ responden di RS Pemerintah dan 38,9\% responden di RS Swasta, yang tidak pernah membuat rencana metoda wawancara yang tepat dalam pertemuan dengan pasien. Padahal untuk dapat mencapai tujuan dari pelaksanaan komunikasi terapeutik terhadap pasien, seharusnya perawat sudah menentukan data spesifik yang akan dicari sekaligus menentukan metoda wawancara yang tepat untuk bisa mendapatkan data tersebut, karena ada berbagai jenis metode wawancara dalam komunikasi keperawatan dan masing-masing digunakan sesuai dengan data yang hendak dicari, maka penentuan metode wawancara yang tepat untuk mendapatkan data spesifik yang hendak dicari merupakan bagian penting yang perlu dilakukan (Mundakir, 2006).

Pada fase kedua (fase orientasi), sebanyak $66,7 \%$ responden di RS Pemerintah tidak pernah memperkenalkan diri, sebanyak $66,7 \%$ responden tidak 
pernah menanyakan nama panggilan harapan yang terlalu tinggi dari pasien kesukaan pasien, dan sebanyak $66,7 \%$ terhadap perawat, karena pasien responden juga tidak pernah menjelaskan menganggap perawat seperti dewa waktu yang dibutuhkan untuk melakukan kegiatan komunikasi terapeutik. Padahal dengan memperkenalkan diri, berarti perawat telah bersikap terbuka dan diharapkan hal ini akan mendorong pasien untuk membuka dirinya. Dengan menanyakan nama panggilan kesukaan pasien, berarti perawat berusaha membina rasa saling percaya, dimana Stuart tahun 1998 menyatakan bahwa hubungan saling percaya merupakan kunci dari keberhasilan suatu hubungan terapeutik. Dan dengan menjelaskan waktu yang dibutuhkan untuk melakukan kegiatan komunikasi terapeutik, maka perawat telah melakukan perumusan kontrak, dimana kontrak sangat penting untuk menjamin kelangsungan sebuah interaksi, karena kontrak bisa dijadikan alat untuk mengingatkan klien akan kesepakatan terkait interaksi yang sedang berlangsung. Selain itu, pada fase orientasi ini juga, sebanyak 22,2\% responden di RS Swasta tidak pernah menjelaskan peran dan tanggung jawab perawat, serta tentang hak dan kewajiban pasien, padahal hal ini perlu dilakukan untuk membuat pasien memahami peran perawat dan menghindari kesalahfahaman dari pasien akan kehadiran perawat, selain itu Geldard tahun 1998 menyatakan bahwa tujuan dari interaksi perlu dijelaskan untuk menghindari adanya penolong yang serba tahu dan serba bisa (Suryani, 2006).

Untuk fase ketiga (fase kerja), Stuart tahun 1998 menyatakan bahwa fase ketiga (fase kerja) merupakan inti dari keseluruhan proses komunikasi terapeutik. Tetapi pada fase kerja ini, sebanyak 47,2\% responden di RS Pemerintah tidak pernah mengajak pasien mengevaluasi cara atau alternatif pemecahan maslah yang dihadapi. Padahal menurut Murray dan Judith tahun 1997, teknik menyimpulkan merupakan usaha untuk memadukan dan menegaskan hal-hal penting dalam percakapan, dan membantu perawat-pasien memiliki pikiran dan ide yang sama, sehingga diharapkan pasien merasa bahwa perawat memahami pesanpesan yang telah disampaikan (Suryani, 2006).

Sedangkan untuk fase keempat (fase terminasi), Stuart tahun 1998 mengatakan bahwa fase ini merupakan akhir dari pertemuan perawat-pasien. Tetapi pada fase terminasi ini, sebanyak $47,2 \%$ responden RS Pemerintah tidak pernah melakukan evaluasi objektif, dan $47,2 \%$ responden juga tidak pernah melakukan evaluasi subjektif. Bahkan sebanyak 61,1\% responden tidak pernah mengakhiri kegiatan pertemuan dengan mengucapkan terima kasih kepada pasien. Padahal 
Brammer dan Mc Donald tahun 1996 menyatakan bahwa meminta pasien untuk menyimpulkan tentang apa yang telah didiskusikan merupakan sesuatu yang sangat berguna, karena dapat membuat perawat mengetahui sejauh mana tujuan telah tercapai. Apabila kegiatan terminasi kurang dilaksanakan dengan baik (terminasi dilakukan secara sepihak dan tiba-tiba), dapat menyebabkan rangkaian kegiatan proses komunikasi terapeutik menjadi tidak efektif, karena adanya perasaan kehilangan, penolakan dan mengingkari manfaat dari interaksi yang telah dilakukan (Suryani, 2006).

Berdasar pada pembahasan mengenai pelaksanaan komunikasi terapeutik perawat di kedua rumah sakit tersebut, terlihat bahwa responden pada kedua rumah sakit melaksanakan setiap fase pada komunikasi terapeutik, tetapi masih banyak langkah dalam masing-masing fase yang tidak dilaksanakan, terutama pada responden di rumah sakit pemerintah. Padahal setiap langkah yang tidak dilaksanakan oleh responden memiliki keterkaitan antara satu sama lain dan dapat mempengaruhi hasil pelaksanaan komunikasi terapeutik secara keseluruhan.

Kondisi tersebut diperkuat oleh hasil analisis uji statistik menggunakan uji independent t-test, yang menunjukkan nilai p-value 0,000, dan berarti ada perbedaan bermakna antara pelaksanaan komunikasi terapeutik di RS Pemeritah dengan pelaksanaan komunikasi terapeutik di RS Swasta. Dimana nilai perbedaan pelaksanaan komunikasi terapeutik antara RS Pemerintah dengan RS Swasta adalah antara -12,627 sampai -4,873; dengan perbedaan rata-rata sebesar $-8,750$.

Nilai lebih tinggi dari responden di rumah sakit swasta, merupakan kondisi yang sesuai dengan analisa hasil distribusi frekuensi jawaban yang telah dibahas diatas, dimana terlihat bahwa responden di RS Swasta lebih lengkap dalam menerapkan setiap langkah dari 4 fase pelaksanaan komunikasi terapeutik. Walaupun ada beberapa langkah yang juga tidak pernah dilaksanankan oleh responden di RS Swasta, tetapi persentasinya lebih kecil daripada RS pemerintah.

\section{Kepuasan Kerja}

Berdasarkan hasil analisis uji statistik dengan menggunakan uji chi square, diperoleh nilai p-value 0,000 , baik untuk RS Pemerintah maupun RS Swasta. Maknanya ada hubungan antara kepuasan kerja responden dengan kepatuhan dalam melaksanakan komunikasi terapeutik terhadap pasien. Untuk analisis hubungan antara kepuasan kerja dengan pelaksanaan komunikasi terapeutik perawat di RS Pemerintah, diperoleh gambaran bahwa persentase responden yang patuh dalam melaksanakan komunikasi terapeutik terhadap pasien lebih besar pada yang 
memiliki kepuasan kerja baik yaitu sebesar 96\% dibandingkan dengan yang memiliki kepuasan kerja kurang yaitu sebesar $36,4 \%$. Begitu juga untuk analisis hubungan antara kepuasan kerja dengan pelaksanaan komunikasi terapeutik perawat di RS Swasta, diperoleh gambaran bahwa persentase responden yang patuh dalam melaksanakan komunikasi terapeutik terhadap pasien lebih besar pada yang memiliki kepuasan kerja baik yaitu sebesar 96,3\% dibandingkan dengan yang memiliki kepuasan kerja kurang yaitu sebesar 33,3\%.

Adanya hubungan antara kepuasan kerja dengan pelaksanaan komunikasi terapeutik ini didukung oleh teori kepuasan kerja Luthans tahun 2006 yang menyatakan bahwa : "Kepuasan kerja adalah keadaan emosi yang senang atau emosi positif yang berasal dari penilaian pekerjaan atau pengalaman kerja seseorang" (Luthans, 2006).

Berdasarkan hasil analisis univariat, dapat diketahui bahwa 69,4\% responden RS Pemerintah memiliki kepuasan kerja baik, dan $75 \%$ responden RS Swasta memiliki kepuasan kerja baik. Selanjutnya hasil analisis uji statistik menggunakan uji independent $t$-test, yang menunjukkan nilai p-value 0,031 dan berarti ada perbedaan bermakna antara kepuasan kerja di RS Pemeritah dengan kepuasan kerja di RS Swasta. Dimana perbedaan kepuasan kerja antara RS Pemerintah dengan RS Swasta adalah antara -14,282 sampai -0,718; dengan perbedaan rata-rata sebesar -7,500.

\section{Motivasi Kerja}

Berdasarkan analisis uji statistik dengan menggunakan uji chi square diperoleh nilai p-value 0,000 baik untuk RS Pemerintah maupun RS Swasta. Hal ini berarti ada hubungan yang bermakna antara motivasi kerja responden dengan kepatuhan dalam melaksanakan komunikasi terapeutik terhadap pasien. Untuk analisis hubungan antara motivasi kerja dengan pelaksanaan komunikasi terapeutik perawat di RS Pemerintah, diperoleh gambaran bahwa persentase responden yang patuh dalam melaksanakan komunikasi terapeutik terhadap pasien lebih besar pada yang memiliki motivasi kerja baik yaitu sebesar 96,2\% dibandingkan dengan yang memiliki motivasi kerja kurang yaitu sebesar 30\%. Begitu juga untuk analisis hubungan antara motivasi kerja dengan pelaksanaan komunikasi terapeutik perawat di RS Swasta, diperoleh gambaran bahwa persentase responden yang patuh dalam melaksanakan komunikasi terapeutik terhadap pasien lebih besar pada yang memiliki motivasi kerja baik yaitu sebesar 96,3\% dibandingkan dengan yang memiliki motivasi kerja kurang yaitu sebesar 33,3\%.

Adanya hubungan antara motivasi kerja dengan pelaksanaan komunikasi terapeutik didukung oleh pernyataan Mangkunegara tahun 2000, bahwa motivasi kerja adalah 
suatu kondisi yang berpengaruh untuk membangkitkan, mengarahkan dan memelihara perilaku yang berhubungan dengan lingkungan kerja. Kondisi yang mempengaruhi perilaku tersebut merupakan kekuatan atau energi yang bersumber dari dalam diri individu itu sendiri maupun dari luar individu (Nursalam, 2002).

Pada hasil analisis multivariat RS Pemerintah, didapatkan nilai OR 36,866 untuk motivasi kerja, yang berarti bahwa motivasi kerja yang baik akan memungkinkan responden di RS Pemerintah lebih patuh dalam melaksanakan komunikasi terapeutik terhadap pasien sebanyak 36,866 kali dibanding motivasi kerja yang tidak baik.

Berdasarkan hasil analisis univariat, dapat diketahui bahwa 72,2\% responden di RS Pemerintah memiliki motivasi kerja baik, dan $75 \%$ responden di RS Swasta memiliki motivasi kerja baik. Hasil analisis uji statistik menggunakan uji independent $t$ test menunjukkan nilai $p$-value 0,045 , yang berarti bahwa ada perbedaan antara motivasi kerja di RS Pemeritah dengan motivasi kerja di RS Swasta. Dimana perbedaan motivasi kerja antara RS Pemerintah dengan RS Swasta adalah antara $-3,127$ sampai $-0,039 ;$ dengan perbedaan rata-rata sebesar -1,583.

\section{Iklim Kerja}

Berdasarkan hasil analisis uji statistik menggunakan uji chi square diperoleh nilai p-value 0,003 untuk RS Pemerintah, dan nilai p-value 0,002 untuk RS Swasta. Hal ini berarti ada hubungan yang bermakna antara iklim kerja responden dengan kepatuhan dalam melaksanakan komunikasi terapeutik terhadap pasien. Untuk analisis hubungan antara iklim kerja dengan pelaksanaan komunikasi terapeutik perawat di RS Pemerintah, diperoleh gambaran bahwa persentase responden yang patuh dalam melaksanakan komunikasi terapeutik terhadap pasien lebih besar pada yang memiliki iklim kerja baik yaitu sebesar 92,6\% dibandingkan dengan yang memiliki iklim kerja kurang yaitu sebesar 33,3\%. Sedangkan untuk analisis hubungan antara iklim kerja dengan pelaksanaan komunikasi terapeutik perawat di RS Swasta, diperoleh gambaran bahwa persentase responden yang patuh dalam melaksanakan komunikasi terapeutik terhadap pasien lebih besar pada yang memiliki iklim kerja baik yaitu sebesar 96\% dibandingkan dengan yang memiliki iklim kerja kurang yaitu sebesar $45,5 \%$.

Adanya hubungan antara iklim kerja dengan pelaksanaan komunikasi terapeutik ini didukung oleh Davis tahun 1996 yang mendefinisikan iklim sebagai suatu konsep sistem yang dinamis, dimana iklim seperti udara dalam ruangan yang mengitari dan 
mempengaruhi segala hal dalam ruangan tersebut. Iklim tidak dapat dilihat dan disentuh, tapi iklim ada dan dapat dirasakan (Davis \& Newstorm, 1996). Selanjutnya Gibson tahun 1996 mendefinisikan iklim organisasi sebagai serangkaian sifat lingkungan kerja, yang dinilai langsung atau tidak langsung oleh karyawan, yang dianggap menjadi kekuatan utama dalam mempengaruhi perilaku (Gibson \& Donelly, 1996). Begitu juga Litwin, Rubin dan Mc.Intyre tahun 1984, mendefinisikan iklim kerja organisasi sebagai segala sesuatu yang terdapat dalam lingkungan kerja, yang dapat dirasakan atau diterima secara langsung ataupun tidak langsung oleh orang-orang yang berada dalam lingkungan kerja tersebut dan mempengaruhi perilakunya (Suyanto, 2009).

Berdasarkan hasil analisis univariat, dapat diketahui bahwa sebanyak 63,9\% responden di RS Pemerintah merasakan iklim kerja baik, dan sebanyak 69,4\% responden di RS Swasta merasakan iklim kerja baik. Hasil analisis uji statistik menggunakan uji independent t-test, yang menunjukkan nilai p-value 0,001 , dan berarti ada perbedaan bermakna antara iklim kerja di RS Pemeritah dengan iklim kerja di RS Swasta. Dimana perbedaan iklim kerja antara RS Pemerintah dan RS Swasta adalah antara -6,280 sampai -1,553; dengan perbedaan rata-rata sebesar -3,917.

\section{Dukungan Teman Kerja}

Berdasarkan hasil analisis uji statistik menggunakan uji chi square diperoleh nilai p 0,001, baik untuk RS Pemerintah maupun RS Swasta. Hal ini berarti ada hubungan antara dukungan teman kerja responden dengan kepatuhan dalam melaksanakan komunikasi terapeutik terhadap pasien. Untuk analisis hubungan antara dukungan teman kerja dengan pelaksanaan komunikasi terapeutik perawat di RS Pemerintah, diperoleh gambaran bahwa persentase responden yang patuh dalam melaksanakan komunikasi terapeutik terhadap pasien lebih besar pada yang memiliki dukungan teman kerja baik yaitu sebesar 92,6\% dibandingkan dengan yang memiliki dukungan teman kerja kurang yaitu sebesar 33,3\%. Sedangkan untuk analisis hubungan antara dukungan teman kerja dengan pelaksanaan komunikasi terapeutik perawat di RS Swasta, diperoleh gambaran bahwa persentase responden yang patuh dalam melaksanakan komunikasi terapeutik terhadap pasien lebih besar pada yang memiliki dukungan teman kerja baik yaitu sebesar 96,2\% dibandingkan dengan yang memiliki dukungan teman kerja kurang yaitu sebesar $40 \%$.

Adanya hubungan antara dukungan teman kerja dengan pelaksanaan komunikasi terapeutik ini didukung oleh teori yang menyatakan bahwa saran, 
nasehat, dan motivasi anggota keluarga ataupun teman dapat mempengaruhi perilaku (Glanz, 1996). Selain itu, dukungan teman kerja ini merupakan faktor penguat (reinforcing factor) dari perilaku pelaksanaan komunikasi terapeutik perawat. Dimana pendapat, dukungan dan kritik baik dari keluarga, teman-teman sekerja atau lingkungannya, merupakan kelompok referensi dari perilaku seseorang yang bersangkutan (Notoatmodjo, 2007).

Pada hasil analisis multivariat RS Pemerintah, didapatkan nilai OR 13,738 untuk dukungan teman, hal ini berarti bahwa dukungan teman kerja yang baik akan memungkinkan responden di RS Pemerintah lebih patuh dalam melaksanakan komunikasi terapeutik terhadap pasien sebanyak 13,738 kali dibanding dukungan teman kerja yang tidak baik. Sedangkan pada hasil analisis multivariat RS Swasta, didapatkan nilai OR 16,209 untuk dukungan teman, yang berarti bahwa dukungan teman yang baik akan memungkinkan responden di RS Swasta lebih patuh dalam melaksanakan komunikasi terapeutik terhadap pasien sebanyak 16,209 kali dibanding dukungan teman yang tidak baik.

Berdasarkan hasil analisis univariat, dapat diketahui bahwa sebanyak $75 \%$ responden di RS Pemerintah memiliki dukungan teman kerja yang baik, dan $72,2 \%$ responden di RS Swasta memiliki dukungan teman kerja yang baik. Hasil analisis uji statistik dengan menggunakan uji independent t-test menunjukkan nilai $p$ value 0,015, yang berarti ada perbedaan antara dukungan teman kerja di RS Pemeritah dengan dukungan teman kerja di RS Swasta. Dimana dapat diketahui bahwa perbedaan dukungan teman kerja antara RS Pemerintah dengan RS Swasta adalah antara -2,404 sampai -0,262; dengan perbedaan rata-rata sebesar -1,333.

\section{Dukungan Kepala Ruang}

Berdasarkan hasil analisis uji statistik dengan menggunakan uji chi square diperoleh nilai p-value 0,008 untuk RS Pemerintah, dan nilai p-value 0,000 untuk RS Swasta. Hal ini berarti ada hubungan antara kepala ruang dengan kepatuhan dalam melaksanakan komunikasi terapeutik terhadap pasien. Untuk analisis hubungan antara dukungan kepala ruang dengan pelaksanaan komunikasi terapeutik perawat di RS Pemerintah, diperoleh gambaran bahwa persentase responden yang patuh dalam melaksanakan komunikasi terapeutik terhadap pasien lebih besar pada yang memiliki dukungan kepala ruang baik yaitu sebesar 92\% dibandingkan dengan yang memiliki dukungan kepala ruang kurang yaitu sebesar 45,5\%. Sedangkan untuk analisis hubungan antara dukungan kepala ruang dengan pelaksanaan komunikasi terapeutik perawat di RS Swasta, diperoleh gambaran bahwa persentase responden 
yang patuh dalam melaksanakan komunikasi terapeutik terhadap pasien lebih besar pada yang memiliki dukungan kepala ruang baik yaitu sebesar 93,3\% dibandingkan dengan yang memiliki dukungan kepala ruang kurang yaitu sebesar $16,7 \%$.

Adanya hubungan antara dukungan kepala ruang dengan pelaksanaan komunikasi terapeutik ini didukung oleh pernyataan Sulvian dan Decker tahun 1989, bahwa kepemimpinan merupakan penggunaan keterampilan seseorang dalam mempengaruhi orang lain, untuk melaksanakan sesuatu dengan sebaikbaiknya sesuai dengan kemampuannya (Suyanto, 2009).

Pada hasil analisis multivariat RS Swasta, didapatkan nilai OR 28,598 untuk dukungan kepala ruang. Hal ini berarti bahwa dukungan kepala ruang yang baik akan memungkinkan responden di RS Swasta lebih patuh dalam melaksanakan komunikasi terapeutik terhadap pasien sebanyak 28,598 kali dibanding dukungan kepala ruang yang tidak baik.

Berdasarkan hasil analisis univariat, dapat diketahui bahwa sebanyak 69,4\% responden RS Pemerintah memiliki dukungan kepala ruang yang baik, dan $83,3 \%$ responden RS Swasta memiliki dukungan kepala ruang yang baik. Hasil analisis uji statistik menggunakan uji independent $t$-test menunjukkan nilai $p$ - value 0,003 , dan berarti ada perbedaan bermakna antara dukungan kepala ruang di RS Pemeritah dengan dukungan kepala ruang di RS Swasta. Dimana perbedaan nilai dukungan kepala ruang RS Pemerintah dengan RS Swasta adalah antara -4,602 sampai -1,009; dengan perbedaan rata-rata sebesar $-2,806$.

\section{Umur}

Berdasarkan hasil analisis univariat, dapat diketahui bahwa sebanyak 63,9\% responden di RS Pemerintah berumur $\leq 33,28$ tahun, dengan umur responden paling muda adalah 26 tahun dan umur responden paling tua adalah 45 tahun. Sedangkan untuk responden di RS Swasta, dapat diketahui bahwa sebanyak 58,3\% responden berumur $\leq 28,08$ tahun, dengan umur responden paling muda adalah 22 tahun dan umur responden paling tua adalah 33 tahun.

Berdasarkan hasil uji statistik menggunakan uji chi square diperoleh nilai p-value 1,000 untuk RS Pemerintah, dan $p$ value 0,618 untuk RS Swasta. Hal ini berarti bahwa tidak ada hubungan antara umur responden dengan kepatuhan dalam melaksanakan komunikasi terapeutik terhadap pasien. Peneliti berpendapat bahwa tidak adanya hubungan antara umur dengan kepatuhan responden dalam pelaksanaan komunikasi terapeutik kemungkinan disebabkan karena responden pada kategori umur manapun, memiliki 
kebiasaan yang sama dalam melaksanakan komunikasi terapeutik. Pendapat peneliti berdasarkan pada hasil penelitian ini, bahwa persentase responden di RS Pemerintah yang patuh dalam melaksanakan komunikasi terapeutik hampir sama, yaitu $78,3 \%$ untuk umur $\leq 33,28$ tahun dan $76,9 \%$ untuk umur $>33,28$ tahun. Selain itu, pada teori konsepsi manusia dalam psikologi kognitif, disebutkan bahwa manusia secara keseluruhan merupakan mahluk yang selalu berusaha memahami lingkungannya dan mahluk yang selalu berpikir. Pada teori dinamika kelompok, Asch menunjukkan kecenderungan orang untuk mengikuti pendapat kelompoknya (Jalaluddin, 2012). Maknanya, manusia secara keseluruhan (yang berumur muda ataupun berumur tua) merupakan mahluk yang memiliki kemampuan sama untuk belajar dan berpikir sebagai usaha mengenal dan memahami lingkungannya, dimana kecenderungan yang biasa dilakukan adalah mengikuti pendapat atau kebiasaan kelompoknya.

Berdasarkan hasil analisis uji statistik menggunakan uji independent t-test, didapatkan nilai p-value 0,000 , yang berarti ada perbedaan antara umur di RS Pemeritah dengan umur di RS Swasta. Dimana perbedaan umur antara RS Pemerintah dengan RS Swasta adalah antara 3,446 sampai 6,943; dengan perbedaan rata-rata sebesar 5,194.

\section{Jenis Kelamin}

Berdasarkan hasil uji statistik dengan menggunakan uji chi square diperoleh nilai p-value 0,746 untuk RS Pemerintah, dan nilai p-value 0,883 untuk RS Swasta. Hal ini berarti bahwa tidak ada hubungan antara jenis kelamin responden dengan kepatuhan dalam melaksanakan komunikasi terapeutik terhadap pasien. Tidak adanya hubungan antara jenis kelamin dengan pelaksanaan komunikasi terapeutik ini didukung oleh pernyataan Budioro yang mengatakan bahwa tidak ada perbedaan yang penting antara karyawan laki-laki dengan karyawan perempuan dalam prestasi kerja, karena tidak ada perbedaan dalam penyelesaian problem, keterampilan analis, motivasi, kepemimpinan dan kemampuan belajar (Budioro, 1998).

Berdasarkan hasil analisis univariat, dapat diketahui bahwa sebanyak 63,9\% responden di RS Pemerintah adalah perempuan, dan $36,1 \%$ responden adalah laki-laki. Sedangkan untuk responden di RS Swasta, dapat diketahui bahwa sebanyak $80,6 \%$ adalah perempuan, dan $19,4 \%$ responden adalah laki-laki. Selanjutnya hasil analisis uji statistik menggunakan uji independent $t$-test, menunjukkan nilai $p$ value 0,118, yang berarti tidak ada perbedaan antara jenis kelamin di RS Pemeritah dengan jenis kelamin di RS Swasta. 


\section{Pendidikan}

Berdasarkan hasil uji statistik dengan menggunakan uji chi square diperoleh nilai p-value 1,000 untuk responden di $\mathrm{RS}$ Pemerintah, dan nilai p-value 0,676 untuk responden di RS Swasta. Hal ini berarti bahwa tidak ada hubungan antara pendidikan responden dengan kepatuhan dalam melaksanakan komunikasi terapeutik terhadap pasien. Peneliti berpendapat bahwa tidak adanya hubungan antara pendidikan dengan kepatuhan responden dalam pelaksanaan komunikasi terapeutik kemungkinan disebabkan karena responden di RS Pemerintah Kota Banjar pada tingkat pendidikan manapun memiliki kebiasaan yang sama dalam melaksanakan komunikasi terapeutik. Pendapat ini berdasarkan pada fakta bahwa jenjang karier keperawatan di Indonesia sulit di bedakan antara SPK, AKPER dan S.Kep/S1. Walaupun pada dasarnya mereka mempunyai perbedaan tingkat pendidikan, namun di rumah sakit mereka mempunyai kesamaan dalam memberikan pelayanan kesehatan di bidang keperawatan. Hak dan tanggung jawab mereka sama saja, baik dalam memberikan obat (injeksi maupun oral), dalam melakukan tindakan seperti memasang infus, NGT ataupun kateter, begitu juga dalam pelaksanaan komunikasi terapeutik. Oleh karena itu, responden yang berpendidikan D3 memiliki kebiasaan pelaksanaan komunikasi terapeutik yang sama dengan responden yang berpendidikan S1.

Berdasarkan hasil analisis univariat, diketahui bahwa bahwa $80,6 \%$ responden di RS Pemerintah berpendidikan D3, dan 19,4\% responden lainnya berpendidikan $\mathrm{S} 1$. Sedangkan untuk responden di RS Swasta, sebanyak $72,2 \%$ responden berpendidikan D3, dan $27,8 \%$ responden lainnya berpendidikan S1. Selanjutnya hasil analisis uji statistik menggunakan uji independent $t$ test menunjukkan nilai $p$-value 0,412 yang berarti tidak ada perbedaan antara pendidikan di RS Pemeritah dengan pendidikan di RS Swasta. Tidak adanya perbedaan pada variabel pendidikan antara kedua rumah sakit ini, disebabkan karena responden untuk penelitian ini adalah sama, baik untuk di RS Pemerintah dan di RS Swasta, yaitu perawat, maka variabel pendidikan tentu tidak akan menunjukkan perbedaan yang bermakna.

\section{Masa Kerja}

Berdasarkan hasil analisis uji statistik dengan menggunakan uji chi square diperoleh nilai p-value 0,964 untuk RS Pemerintah, dan nilai p-value 1,000 untuk RS Swasta. Hal ini berarti bahwa tidak ada hubungan antara masa kerja responden dengan kepatuhan dalam melaksanakan komunikasi terapeutik terhadap pasien. Peneliti berpendapat bahwa tidak adanya hubungan antara masa kerja dengan pelaksanaan komunikasi terapeutik, 
kemungkinan dipengaruhi oleh stres kerja yang dialami oleh perawat masa kerja lama.

Sehingga pada akhirnya walaupun memiliki pengalaman kerja lebih banyak, tetapi perawat masa kerja lama mempunyai kebiasaan pelaksanaan komunikasi terapeutik yang sama saja dengan perawat masa kerja baru. Selanjutnya hal ini juga didukung oleh Keliat tahun 1999 yang menyatakan bahwa peran perawat di IGD dan ruang rawat inap sangat penting karena merupakan ujung tombak pelayanan, dan perawat merupakan tenaga paling lama kontak atau berhubungan dengan pasien dan keluarga, dimana hal ini dapat menjadi stressor yang kuat pada perawat didalam lingkungan pekerjaan. Kemudian Abraham dan Steanly tahun 1997, menyatakan bahwa dalam pelayanan kesehatan perawat yang mengalami stres kerja berat dapat kehilangan motivasi, mengalami kejenuhan yang berat dan tidak masuk kerja lebih sering (Utomo, 2009).

Hasil analisis univariat menunjukkan bahwa sebanyak 55,6\% responden di RS Pemerintah memiliki masa kerja $\leq 9,39$ tahun, dan sebanyak $58,3 \%$ responden memiliki masa kerja $\leq 4,19$ tahun. Selanjutnya hasil analisis uji statistik dengan menggunakan uji independent t-test menunjukkan nilai $p$-value 0,000 , yang berarti bahwa ada perbedaan antara masa kerja di RS Pemeritah dengan masa kerja di RS Swasta. Dimana dapat diketahui bahwa perbedaan masa kerja antara RS Pemerintah dengan RS Swasta adalah antara 3,386 sampai 7,003; dengan perbedaan rata-rata sebesar 5,194. Perbedaan masa kerja antara responden di RS Pemerintah dengan di RS Swasta kemungkinan disebabkan perbedaan umur berdirinya kedua rumah sakit, dimana RSUD Kota Banjar merupakan rumah sakit pertama di Kota Banjar yang sudah berdiri sejak tahun 1978, sedangkan RS Mitra Idaman merupakan rumah sakit swasta yang baru berdiri tahun 2004, sehingga perbedaan umur berdirinya ini juga mempengaruhi masa kerja dari responden masing-masing rumah sakit.

\section{Pengetahuan}

Berdasarkan hasil analisis uji statistik dengan menggunakan uji chi square diperoleh nilai p-value 0,643 untuk RS Pemerintah, dan nilai p $0,883>\alpha(0,05)$ untuk RS Swasta. Hal ini berarti bahwa tidak ada hubungan antara pengetahuan responden dengan kepatuhan dalam melaksanakan komunikasi terapeutik terhadap pasien. Tidak adanya hubungan antara pengetahuan dengan pelaksanaan komunikasi terapeutik ini didukung oleh pernyataan Green yang menyebutkan bahwa peningkatan pengetahuan tidak selalu menyebabkan perubahan perilaku, walaupun pengetahuan merupakan faktor penting dalam perubahan perilaku (Green, 2000). Selanjutnya Winkel menyatakan bahwa pengetahuan yang diperoleh 
seseorang akan menimbulkan pengertian dan pemahaman terhadap pengetahuan tersebut. Dengan memahami sesuatu hal yang dipelajari, seseorang akan dapat mengadakan penilaian. Penilaian ini dapat positif atau negatif. Penilaian yang positif akan menimbulkan sikap positif, yang akhirnya akan berpengaruh pada perilaku positif terhadap sesuatu yang dipelajari tersebut. Begitu juga sebaliknya, penilaian yang negatif akan menimbulkan sikap negatif, yang akhirnya akan berpengaruh pada perilaku negatif terhadap sesuatu yang dipelajari tersebut (Winkel, 1986).

Hasil analisis univariat menunjukkan bahwa 75\% responden di RS Pemerintah memiliki pengetahuan baik, dan bahwa $80,6 \%$ responden di RS Swasta memiliki pengetahuan baik. Berdasarkan hasil analisis analisis uji statistik menggunakan uji independent t-test, didapatkan nilai $p$ value 0,373 yang berarti tidak ada perbedaan antara pengetahuan di RS Pemeritah dengan pengetahuan di RS Swasta. Tidak adanya perbedaan bermakna antara responden di RS Pemerintah dan di RS Swasta pada penelitian ini, karena responden di kedua rumah sakit adalah sama yaitu perawat, dimana semua perawat tentu memiliki pengetahuan yang sama mengenai komunikasi terapeutik, karena merupakan salah satu cabang ilmu keperawatan, maka variabel pengetahuan (mengenai komunikasi terapeutik) tentu tidak akan menunjukkan perbedaan yang bermakna.

\section{Sikap}

Berdasarkan hasil analisis uji statistik dengan menggunakan uji chi square diperoleh nilai p-value 0,479 untuk RS Pemerintah, dan nilai p-value 0,676 untuk RS Swasta. Hal ini berarti bahwa tidak ada hubungan antara sikap responden dengan kepatuhan dalam melaksanakan komunikasi terapeutik terhadap pasien. Tidak adanya hubungan antara pengetahuan dengan pelaksanaan komunikasi terapeutik ini didukung oleh pernyataan Atkinson dalam Azwar tahun 1995 menyatakan bahwa sekalipun diasumsikan bahwa sikap merupakan predisposisi evaluasi yang banyak menentukan cara individu bertindak, akan tetapi sikap dan tindakan sering kali jauh berbeda. Hal ini karena tindakan nyata ditentukan tidak hanya oleh sikap, akan tetapi oleh berbagai faktor eksternal lainnya. Sikap tidaklah sama dengan perilaku, dan perilaku tidaklah selalu mencerminkan sikap seseorang, sebab sering kali terjadi bahwa seseorang memperlihatkan tindakan yang bertentangan dengan sikapnya (Kholid, 2012).

Berdasarkan hasil analisis univariat, dapat diketahui bahwa sebanyak $66,7 \%$ responden RS Pemerintah memiliki sikap baik, dan 72,2\% responden RS Swasta memiliki sikap baik. Selanjutnya 
berdasarkan hasil analisis uji statistik dengan menggunakan uji independent t-test, diketahui bahwa nilai p-value 0,044 yang berarti ada perbedaan antara sikap di RS Pemeritah dengan sikap di RS Swasta. Selanjutnya dapat diketahui bahwa perbedaan sikap antara RS Pemerintah dengan RS Swasta adalah antara $-2,851$ sampai -0,038; dengan perbedaan rata-rata sebesar -1,444. Nilai rata-rata sikap responden di RS Swasta yang lebih baik daripada nilai rata-rata sikap responden di RS Pemerintah kemungkinan disebabkan oleh tuntutan untuk memberikan atau menampilkan performa kerja terbaik yang disampaikan oleh manajemen rumah sakit, sehingga dalam kondisi apapun, melayani pasien dengan baik tetap harus menjadi prioritas.

\section{SIMPULAN}

Berdasarkan hasil penelitian, disimpulkan beberapa hal sebagai berikut: Ada perbedaan yang signifikan pada pelaksanaan komunikasi terapeutik perawat di RS Pemerintah dan di RS Swasta, dimana pelaksanaan komunikasi terapeutik perawat RS swasta lebih baik.

Faktor-faktor yang berhubungan secara signifikan dengan pelaksanaan komunikasi terapeutik perawat di RS Pemerintah maupun di RS Swasta adalah sama, yaitu variabel kepuasan kerja, motivasi kerja, iklim kerja, dukungan teman kerja dan dukungan kepala ruang rawat inap.

Faktor yang paling dominan berpengaruh terhadap kepatuhan perawat di RS Pemerintah dalam melaksanakan komunikasi terapeutik adalah motivasi kerja dengan nilai Odd Ratio 36,866, artinya bahwa motivasi kerja yang baik akan memungkinkan responden di RS Pemerintah lebih patuh dalam melaksanakan komunikasi terapeutik terhadap pasien sebanyak 36,866 kali dibanding motivasi kerja yang tidak baik. Sedangkan di RS Swasta adalah dukungan kepala ruang rawat inap dengan nilai $O d d$ Ratio 28,598, artinya bahwa dukungan kepala ruang rawat inap yang baik akan memungkinkan responden di RS Swasta lebih patuh dalam melaksanakan komunikasi terapeutik terhadap pasien sebanyak 28,598 kali dibanding dukungan kepala ruang rawat inap yang tidak baik.

Faktor lain yang berpengaruh secara bersama-sama terhadap pelaksanaan komunikasi terapeutik di RS Pemeritah adalah dukungan teman dengan nilai $O d d$ Ratio 13,738 , artinya bahwa dukungan teman kerja yang baik akan memungkinkan responden di RS Pemerintah lebih patuh dalam melaksanakan komunikasi terapeutik terhadap pasien sebanyak 13,738 kali dibanding dukungan teman kerja yang tidak baik. Sedangkan di RS Swasta adalah dukungan teman dengan nilai Odd Ratio 
16,209, artinya bahwa dukungan teman yang baik akan memungkinkan responden di RS Swasta lebih patuh dalam melaksanakan komunikasi terapeutik terhadap pasien sebanyak 16,209 kali dibanding dukungan teman yang tidak baik.

Besarnya sumbangan variabel motivasi kerja dan dukungan teman kerja secara bersama-sama terhadap variabel pelaksanaan komunikasi terapeutik perawat di RS Pemerintah adalah sebesar 99,9\% dan selebihnya atau $0,1 \%$ ditentukan oleh variabel lain di luar penelitian ini. Sedangkan besarnya sumbangan variabel dukungan kepala ruang rawat inap dan dukungan teman kerja secara bersama-sama terhadap variabel pelaksanaan komunikasi terapeutik perawat di RS Swasta adalah sebesar $99,6 \%$ dan selebihnya atau $0,4 \%$ ditentukan oleh variabel lain di luar penelitian ini.

Terdapat perbedaan yang bermakna pada pelaksanaan komunikasi terapeutik di RS Pemeritah dengan pelaksanaan komunikasi terapeutik di RS Swasta, dengan p-value 0,000. Perbedaan yang bermakna antara RS Pemerintah dengan RS Swasta nampak pada variabel: umur, masa kerja, sikap, kepuasan kerja, motivasi kerja, iklim kerja, dukungan teman kerja dan dukungan kepala ruang rawat inap. Perbedaan yang tidak bermakna antara RS Pemerintah dengan RS Swasta nampak pada variabel: pendidikan, jenis kelamin, dan pengetahuan.

\section{KEPUSTAKAAN}

Redaksi. 2011. Undang-Undang Kesehatan (UU RI No.36 Th. 2009). Penerbit Sinar Grafika. Jakarta.

DepKes. 2009. Sistem Kesehatan Nasional: Bentuk dan Cara Penyelenggaraan Pembangunan Kesehatan. Depkes RI. Jakarta, $2009 . \quad$ Dalam http://www.depkes.go.id/downloads/S KN\%20final.pdf (diakses tanggal 03 Februari 2013).

Azwar, A. 1994. Program menjaga mutu pelayanan kesehatan. IDI. Jakarta.

DepKes. 2010. Langkah Rumah Sakit mencapai pelayanan standar internasional. Depkes RI: Humas Direktorat Jenderal Bina Upaya Kesehatan Kementerian Kesehatan RI. Jakarta. Dalam http://buk.depkes.go.id/index.php?opt ion=com_content $\&$ view=article $\&$ id $=$ 197:langkah-rumah-sakit-mencapaipelayanan-standar-internasional (diakses tanggal 20 Maret 2013).

Aditama, T.Y. 2004. Manajemen Administrasi Rumah Sakit. Universitas Indonesia. Jakarta.

Royani. 2010. Hubungan Sistem Penghargaan Dengan Kinerja Perawat Dalam Melaksanakan Asuhan 
Keperawatan di Rumah Sakit Daerah Cilegon Banten. (Tesis).

Abraham \& Shanley. 1997. Psikologi Sosial Untuk Perawat. EGC. Jakarta.

Machfoedz, M. 2009. Komunikasi keperawatan: Komunikasi Terapeutik. Penerbit Ganbika. Yogyakarta.

Suryani. 2006. Komunikasi Terapeutik: Teori \& Praktik. EGC. Jakarta.

Mundakir. 2006. Komunikasi Keperawatan: Aplikasi dalam pelayanan. Graha Ilmu. Yogyakarta.

Nugroho, H. A \& Aryati, S. 2009. Hubungan Antara Komunikasi

Terapeutik Perawat Dengan Kepuasan Pasien Di Rumah Sakit Islam Kendal. FIKKes UNIMUS: Jurnal Keperawatan UNIMUS, Volume 2, Nomor 2. Edisi Maret 2009: 36-41. UNIMUS. Semarang.

Lupiyoadi, R \& Hamdani, A. 2009. Manajemen Pemasaran Jasa. Salemba Empat. Jakarta.

Nursalam. 2002. Manajemen Keperawatan: Aplikasi Dalam Praktik Keperawatan Profesional. Salemba Medika. Jakarta.

Davis, K. \& Newstorm, J. W. 1996. Perilaku Dalam Organisasi. Terjemahan Agus Darma Jilid I. Penerbit Erlangga. Jakarta.

Gibson, I. \& Donelly Jr. 1996. Organisasi: Perilaku Struktur Proses. Terjemahan
Nunuk Ardriani Jilid I. Penerbit Binarupa Aksara. Jakarta.

Suyanto. 2009. Mengenal Kepemimpinan dan Manajemen Keperawatan di Rumah Sakit. Mitra Cendikia Press. Yogyakarta.

Luthans, Fred. 2006. Perilaku Organisasi 10th. Edisi Indonesia. Penerbit ANDI. Yogyakarta.

Notoatmodjo, S. 2007. Promosi Kesehatan dan Ilmu Perilaku. Rineka Cipta. Jakarta.

Lawrence W. Green \& Marshall W. Kreuter. 2000. Health Promotion Planning: an Educational and Environmental Approach Second Edition. Mayfield Publishing Company. California.

Kholid, A. 2012. Promosi Kesehatan: Dengan Pendekatan Teori Perilaku, Media dan Aplikasinya. PT. Raja Grafindo Persada. Jakarta.

Glanz, K, Lewis. M. F. \& Rimer. K. B. 1996. Health Behaviour and Health Education: Theory, Research, and Practice. Jossey-Bass A Willey Company. San Fransisco.

Jalaluddin, R. 2012. Psikologi Komunikasi. PT. Remaja Rosdakarya. Bandung.

Budioro, B. 1998. Pengantar Pendidikan dan Penyuluhan Kesehatan Masyarakat. Fakultas Kesehatan Masyarakat Universitas Diponegoro. Semarang. 
Utomo, D. P. 2009. Hubungan Stres Kerja Dengan Adaptasi Pada Perawat di Instalasi Gawat Darurat RSUD Pandan Arang Boyolali. (Skripsi). Dalam: http://etd.eprints.ums.ac.id/4395/1/J2 20060047.pdf. (diakses tanggal 12 Februari 2014).

Winkel, W.S. 1986. Psikologi Pendidikan dan Evaluasi Belajar. Gramedia. Jakarta. 